\title{
Pengaruh Pembelajaran Assurance, Relevance, Interest, Assessment, Satisfaction Berbantuan Etnomatematika terhadap Kemampuan Pemecahan Masalah
}

\author{
Nia Aprilyani ${ }^{*}{ }^{*}$ Arif Rahman Hakim ${ }^{2}$ \\ 1,2Program Studi Pendidikan Matematika, Universitas Indraprasta PGRI, Jakarta, Indonesia; \\ ${ }^{1 *}$ niaaprilyani37@gmail.com; ${ }^{2}$ arsyanriftyrahman@gmail.com
}

Info Artikel: Dikirim: 5 September 2019; Direvisi: 21 Oktober 2019; Diterima: 5 Maret 2020

Cara sitasi: Aprilyani, N., \& Hakim, A. R. (2020). Pengaruh Pembelajaran Assurance, Relevance, Interest, Assessment, Satisfaction Berbantuan Etnomatematika terhadap Kemampuan Pemecahan Masalah. JNPM (Jurnal Nasional Pendidikan Matematika), 4(1), 61-74.

\begin{abstract}
Abstrak. Penelitian ini memiliki tujuan untuk mengetahui pengaruh penerapan pembelajaran Assurance, Relevance, Interest, Assessment, Satisfaction (ARIAS) berbantuan etnomatematika terhadap kemampuan pemecahan masalah matematis siswa. Metode penelitian eksperimen dengan desain posttest only control group. Sampel penelitian adalah siswa kelas VII MTs Al-Wathoniyah 08 Jakarta. Pengambilan sampel penelitian berdasar pada populasi terjangkau dengan teknik multistage sampling, diperoleh dua kelas, yaitu satu kelas sebagai kelompok eksperimen dan satu kelas sebagai kelompok kontrol. Teknik analisis data dilakukan secara deskriptif dan secara inferensial dengan terlebih dahulu dilakukan uji prasyarat analisis berupa uji normalitas dan uji homogenitas. Berdasarkan pada hasil pengujian hipotesis, hasil penelitian ini dapat disimpulkan bahwa penerapan pembelajaran ARIAS berbantuan etnomatematika berpengaruh secara signifikan terhadap kemampuan pemecahan masalah matematis siswa kelas VII.
\end{abstract}

Kata Kunci: Pembelajaran ARIAS, Etnomatematika, Kemampuan Pemecahan Masalah Matematis.

\begin{abstract}
This study aimed to know the effect of assurance, relevance, interest, assessment, and satisfaction (ARIAS) learning assisted by ethnomathematics on mathematical problemsolving ability. The research method used was an experimental method with posttest only

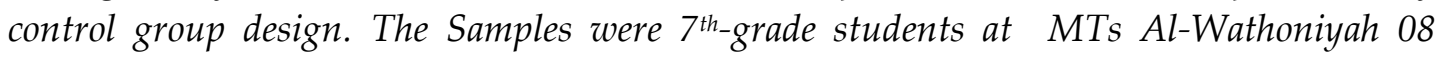
Jakarta. A sampling of this study based on an accessible population with a multistage sampling technique obtained two classes; there were an experimental class and a control class. The data analysis technique was done descriptively and inferentially, by firstly tested normality and homogeneity tests. Based on hypothesis testing, it can be concluded that the application of ARIAS learning assisted by ethnomathematics significantly affects on mathematical problem-solving ability in $7^{\text {th }}$-grade students.
\end{abstract}

Keywords: ARIAS Learning, Ethnomatematics, Mathematical Problem Solving Ability. 


\section{Pendahuluan}

Matematika mempunyai peran penting dalam setiap mata pelajaran, seperti pelajaran IPA, komputer, bahasa, dan lain sebagainya yang didalamnya berkaitan erat dengan matematika. Liberna (2012) menyatakan bahwa matematika adalah dasar dari aplikasi dalam kehidupan sehari-hari dan merupakan induk dari semua jenis kealaman. Matematika merupakan ilmu tentang metode dan proses untuk menemukan suatu konsep yang tepat, di dalamnya terdapat bentuk, susunan, kuantitas, dan ukuran (Franklin, 2015). Melalui kegiatan pembelajaran matematika, salah satu harapannya adalah pada diri siswa dapat tumbuh berbagai kemampuan berpikir, seperti: kreatif, kritis, efektif, sistematis, logis, cermat, dan efisien dalam menyelesaikan masalah matematis.

Sebagian besar siswa menjadikan matematika sebagai mata pelajaran yang paling sulit dan menjadi hal yang menakutkan. Menurut Liberna (2012), Supriyanto (2014), Binangun \& Hakim (2016), pada umumnya matematika merupakan salah satu mata pelajaran yang tidak disenangi oleh sebagian siswa, sebagian siswa menganggap matematika sebagai pelajaran yang tidak mudah dipahami, karena terlalu banyak menghafal rumus, soal-soal rumit dan siswa menghindari kesulitan-kesulitan tersebut. Sehingga, secara umum minat belajar siswa menjadi berkurang karena faktor tersebut dan kurang memperhatikan ketika guru memberi penjelasan.

Maka, untuk menumbuhkan perhatian siswa ketika pembelajaran matematika, dibutuhkan strategi yang menarik dan efektif digunakan. Namun demikian, tentu tidak mudah agar siswa dapat mempelajari materi pelajaran matematika, hal ini disebabkan oleh keterkaitan materi dengan urutan langkah-langkah penyelesaian masalah secara sistematis. Berdasarkan prinsip-prinsip dan standar matematika sekolah dari National Council of Teacher Mathematics (NCTM) (2000), pemecahan masalah merupakan salah satu bagian yang diperlukan untuk melengkapi pembelajaran matematika, yang dapat juga berarti bahwa untuk meningkatkan pemikiran kreatif, logis, kritis, dan sistematis, siswa harus menguasai rangkaian pemecahan masalah pada matematika. Menurut Polya (Astriyani, 2016) ada empat langkah penyelesaian masalah matematika, yaitu: (1) memahami masalah, (2) membuat rencana pemecahan masalah, (3) melaksanakan pemecahan masalah, dan (4) melihat (mengecek) kembali. Pemecahan masalah merupakan salah satu tujuan dalam proses pembelajaran. Menurut NCTM (2000) proses berpikir matematika dalam pembelajaran matematika meliputi lima kompetensi standar utama, salah satunya adalah kemampuan pemecahan masalah. Oleh karena itu, guru 
dalam kegiatan pembelajaran perlu menerapkan metode belajar yang bervariasi sesuai dengan kondisi siswa, agar siswa dapat mengembangkan pengetahuan yang dimiliki.

Pemilihan sekaligus penggunaan sebuah metode dan teknik pembelajaran yang dianggap tepat tentunya dapat berpengaruh terhadap kemampuan

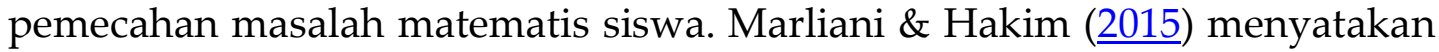
bahwa teknik atau metode atau model pembelajaran yang digunakan oleh guru tidak boleh terpaku hanya pada satu pilihan saja, melainkan harus berbeda-beda agar pembelajaran tidak monoton dan tidak membosankan. Seyogyanya, seorang guru harus dapat memilih metode yang dianggap bersesuaian dengan hal yang menjadi kebutuhan di ruang belajar. Namun pada kenyataannya, sebuah metode belajar yang dipraktikkan guru kurang bervariasi, guru cenderung memberikan metode konvensional. Menurut Kresma (2014), siswa yang menggunakan pembelajaran konvensional dalam proses belajarnya hanya mendengarkan guru menjelaskan, tanpa ada aktivitas yang lebih dan lebih monoton. Sehingga hal ini berakibat pada aktivitas siswa dalam ruang belajar menjadi kurang baik, karena jalannya rangkaian kegiatan pembelajaran yang terjadi hanya satu arah, monoton, dan menimbulkan rasa bosan pada setiap siswa di saat mengikuti pembelajaran matematika.

Rendahnya kemampuan pemecahan masalah matematis pada siswa juga dialami di MTs Al-Wathoniyah 08 Jakarta kelas VII yang memiliki karakteristik relatif identik dengan MTs/SMP lainnya di Indonesia. Berdasarkan hasil wawancara dengan guru MTs Al-Wathoniyah 08 Jakarta pada tahun pelajaran 2018/2019, diperoleh informasi bahwa dalam mengerjakan latihan yang diberikan guru, hanya sebagian siswa yang mampu menjawab dengan benar. Sebagian besar siswa kurang memahami konteks materi yang dijelaskan guru. Berbagai hal yang menjadi kendala siswa dalam memahami materi pelajaran diperkirakan berkaitan dengan langkah guru memberikan pengajaran yang kurang variatif. Guru pelajaran matematika di MTs Al-Wathoniyah 08 Jakarta rutin menerapkan metode ceramah dan diskusi sederhana, serta pernah menggunakan pembelajaran kooperatif Student Teams Achievement Division. Terkait hal tersebut, salah satu solusi untuk menambah semangat siswa dalam belajar adalah guru mengganti metode pembelajaran.

Berdasarkan nilai akhir semester gasal tahun ajaran 2018/2019 MTs Al Wathoniyah 08, nilai rata-rata siswa masih kurang dari Kriteria Ketuntasan Minimum (KKM). KKM yang ditetapkan adalah 70, sedangkan nilai rata-rata 
kelas VII sebesar 65. Sesuai data tersebut dapat disimpulkan bahwa hasil belajar untuk mata pelajaran matematika masih rendah dan mata pelajaran matematika masih dianggap sulit dan kurang diminati oleh siswa di sekolah tersebut. Informasi lain berdasarkan rangkaian kegiatan observasi pra penelitian yang sudah dilakukan di MTs Al-Wathoniyah 08 Jakarta diperoleh informasi dari guru matematika sekolah tersebut bahwa pembelajaran masih berpusat pada guru, siswa masih kurang mandiri dan cenderung pasif dalam kegiatan pembelajaran.

Salah satu kajian pada mata pelajaran matematika yang disampaikan di kelas VII adalah pokok bahasan tentang aritmetika sosial. Pokok bahasan aritmetika sosial ini erat kaitannya dengan aplikasi aljabar di lingkungan sehari-hari siswa. Pokok bahasan kajian aritmetika sosial, siswa diarahkan agar dapat menyelesaikan masalah dengan menggunakan daya nalar dan kreativitas yang dimilikinya. Permasalahan di lingkungan sehari-hari siswa sangat erat kaitannya tentang angka sekaligus perhitungan yang dituangkan dalam soal berbentuk uraian atau soal cerita. Permasalahan sehari-hari yang dialami siswa seringkali berupa kegiatan jual beli yang dituangkan dalam bentuk soal cerita, sehingga memberikan deskripsi nyata bahwa matematika erat kaitannya dengan aktivitas siswa. Tetapi, pada kenyataannya, kesulitankesulitan masih dialami siswa, kesulitan yang dialami adalah siswa belum paham dengan inti permasalahannya.

Menurut Hayuningtyas (ㅁ12), kesulitan siswa dalam mengerjakan permasalahan tentang aritmetika sosial adalah siswa kurang memahami konsep dari aritmetika sosial, siswa kurang teliti dalam pemakaian simbol dan pemakaian rumus, dan siswa kurang teliti dalam perhitungan dan penyelesaian soal. Untuk menumbuhkan kemampuan dalam menyelesaikan permasalahan matematika pada diri siswa tentang pokok bahasan aritmetika sosial, seyogyanya dibutuhkan suatu metode belajar yang efektif dan kreatif serta efisien, sehingga dapat meningkatkan aktivitas siswa dalam belajar.

Bentuk pembelajaran efektif kreatif yang dapat mengatasi permasalahan tersebut yaitu pembelajaran Assurance, Relevance, Interest, Assessment, dan Satisfaction (ARIAS). Menurut Rahman \& Amri (2014), model pembelajaran ARIAS sangat baik diterapkan dalam kegiatan pembelajaran, minat siswa menjadi meningkat karena pembelajaran dikaitkan dengan kehidupan nyata siswa, meningkatkan rasa percaya diri, adanya evaluasi, dan menumbuhkan rasa bangga pada diri siswa dengan diberikannya reward. Model pembelajaran ARIAS memuat lima komponen, yaitu: Assurance (percaya diri), Relevance (relevansi atau sesuai dengan kehidupan siswa), Interest 
(minat atau perhatian), Assessment (evaluasi), dan Satisfaction (penguatan). Kelima komponen pembelajaran tersebut terikat satu sama lain, tidak dapat dipisahkan (Siahaan, Setiawan, \& Sa'adah, 2010). Berdasarkan hasil penelitian Wulandari \& Supriyono (2014), dan penelitian Hindayani, Sumantri, \& Parmiti (2013), kemampuan pemecahan masalah matematis siswa meningkat setelah menggunakan model pembelajaran ARIAS.

Sesuai beberapa peneliti tersebut dapat disimpulkan bahwa pembelajaran ARIAS dapat meningkatkan kemampuan pemecahan masalah siswa. Masalah yang siswa alami bukan hanya kemampuan pemecahan masalah saja. Disamping berkurangnya minat dari siswa dalam belajar matematika, siswa juga berkurang pengetahuannya pada budaya Indonesia. Banyak faktor yang menjadi penyebab hal ini, diantaranya berupa tumbuh kembang suatu kemajuan di bidang IPTEK yang hampir tanpa filter. Tentang hal rendahnya kesadaran siswa atas budaya lokal, perlu adanya usaha untuk meningkatkan kesadaran budaya. Usaha yang menjadi alternatif untuk dilakukan adalah dengan menerapkan beragam hal yang bersesuaian dengan budaya ke dalam pembelajaran, yaitu pembelajaran berbasis budaya. Salah satu bentuk nyata belajar matematika yang fokus berorientasi pada budaya dan kearifan lokal adalah etnomatematika.

Menurut Massarwe, Verner, \& Bshouty (2012) hal efektif yang diperlukan untuk mengubah pembelajaran salah satunya adalah budaya. Etnomatematika menjadi pengaruh penting dalam pembelajaran, karena dapat meningkatkan pengetahuan budaya pada diri siswa yang dalam konteks ini sesuai dengan pendapat Wahyuni (2013) yang dijelaskan dengan menerapkan etnomatematika dalam pembelajaran, siswa akan lebih mudah paham terhadap materi yang diberikan, karena materi dikaitkan dengan budaya yang terdapat dalam kehidupan sehari-hari siswa. Rachmawati (2012) juga menjelaskan bahwa etnomatematika adalah salah satu solusi untuk pembelajaran matematika yang dikaitkan dengan budaya yang sesuai dengan latar belakang siswa, sehingga pengetahuan budaya siswa menjadi bertambah. Menyampaikan konteks budaya kepada siswa bisa di saat pembelajaran berlangsung sekaligus dapat disampaikan juga dalam bentuk soal-soal pemecahan masalah. Senada juga dengan pendapat Hartono \& Saputro (2018) menyatakan bahwa pendidikan dan budaya merupakan bahasa simbolik, tentunya dengan simbol-simbol matematika, budaya dapat digambarkan dengan simbol tersebut.

Etnomatematika menjadi suatu jembatan antara matematika dengan budaya siswa, sehingga matematika dapat diterapkan dalam kehidupan sehari-hari 
siswa dan membuktikan bahwa belajar matematika tidak hanya di sekolah. Hartono \& Saputro (2018) menjelaskan bahwa matematika sangat penting dipelajari, karena matematika merupakan jembatan antara matematika dalam kehidupan sehari-hari berdasar pada budaya tradisional dengan matematika di sekolah, sehingga secara otomatis matematika dapat melestarikan budaya. Konsep etnomatematika berisi tentang matematika yang dijalankan dalam kebudayaan tertentu. Budaya dalam etnomatematika ini mengacu pada konsep budaya yang berlaku di masyarakat untuk suku atau kelompok bangsa yang identik sesuai dengan kumpulan kaidah atau aturan umum (Yusuf, Saidu, \& Halliru, 2010).

Dengan demikian, selain meningkatkan kemampuan pemecahan masalah matematis siswa, siswa pun mendapat pengetahuan mengenai budaya. Berdasarkan latar belakang tersebut, maka peneliti melakukan penelitian mengenai pembelajaran Assurance, Relevance, Interest, Assessment, Satisfaction berbantuan etnomatematika.

\section{Metode}

Penelitian ini menggunakan metode eksperimen, dengan perlakuan berupa pembelajaran Assurance, Relevance, Interest, Assessment, Satisfaction (ARIAS), berbantuan etnomatematika dan perlakuan berupa pembelajaran kooperatif tipe Student Teams Achievement Division (STAD) berbantuan etnomatematika. Pembelajaran kooperatif tipe STAD sudah pernah diaplikasikan di MTs AlWathoniyah 08 Jakarta, sehingga dijadikan sebagai pembanding dari pembelajaran ARIAS. Penelitian ini mempunyai dua variabel, yaitu kemampuan pemecahan masalah matematis sebagai variabel terikat $(Y)$ dan pembelajaran ARIAS berbantuan etnomatematika sebagai variabel bebas (X). Desain eksperimen dengan posstest only control grup ditampilkan pada Gambar 1.

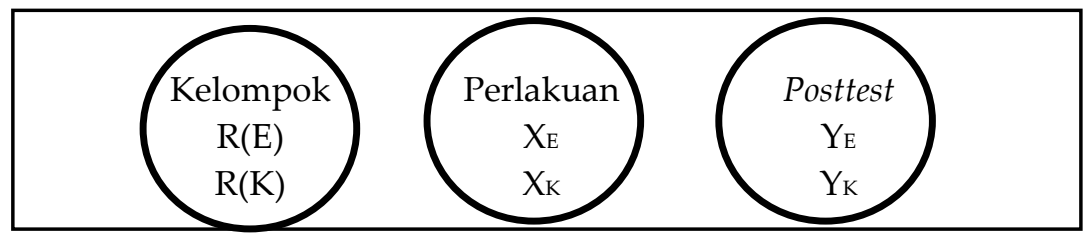

Gambar 1. Desain Penelitian Kelas Eksperimen dan Kelas Kontrol

Pengambilan sampel penelitian ini pada populasi terjangkau dengan teknik multistage sampling, hal ini disebabkan karena pemilihan sampel melalui dua tahap, yaitu: (1) memilih kelas secara simple random sampling, yaitu dari dua rombongan belajar kelas paralel di MTs Al-Wathoniyah 08 Jakarta ditetapkan random untuk dijadikan kelas rombongan belajar eksperimen dan 
kelas rombongan belajar kontrol. Untuk tahapan pertama ini, setelah dilakukan pengundian, diperoleh rombongan belajar VII-B sebagai kelompok eksperimen dan rombongan belajar VII-A sebagai kelompok kontrol. Kemudian, (2) memilih dan menetapkan responden untuk dijadikan subjek penelitian secara purposive sampling, yaitu untuk menetapkan jumlah responden di masing-masing kelas, baik eksperimen maupun kontrol. Untuk tahapan kedua ini, ditetapkan jumlah responden di masing-masing kelompok adalah 31 siswa. Pengolahan data dilakukan dengan menggunakan uji t setelah semua asumsi prasyarat uji telah dipenuhi.

\section{Hasil dan Pembahasan}

Sesudah rangkaian kegiatan pembelajaran selesai, dilaksanakan posttest bentuk essai dengan tujuh butir soal yang telah diuji validitas dan reliabilitasnya. Deskripsi data kemampuan pemecahan masalah matematis kelas kontrol dan eksperimen dapat dilihat pada Tabel 1.

Tabel 1. Deskripsi Data Kemampuan Pemecahan Masalah Matematis Siswa

\begin{tabular}{ccc}
\hline Perhitungan Statistik & Kelas Eksperimen & Kelas Kontrol \\
\hline$N$ & 31 & 31 \\
$\bar{\chi}$ & 80,21 & 75,84 \\
$S^{2}$ & 32,41 & 19,61 \\
$S$ & 5,69 & 4,43 \\
\hline
\end{tabular}

Tabel 1 menunjukan bahwa kemampuan pemecahan masalah matematis siswa pada kelompok eksperimen dan siswa pada kelompok kontrol menunjukkan hasil yang baik. Hal ini karena beberapa faktor, yaitu: (1) penggunaan etnomatematika di ruang kelas yang dapat dikaitkan dengan kehidupan sehari-hari siswa, (2) siswa dapat lebih kreatif dan kritis dalam proses belajar, karena pembelajaran yang digunakan merupakan student centered bukan teacher centered, dan (3) siswa dibiasakan berkelompok atau mandiri dalam menyelesaikan permasalahan tentang matematika. Sedangkan faktor yang membedakan nilai kelas eksperimen lebih besar dari kelas kontrol, yaitu: (1) Setiap memulai pembelajaran, di dalam kelas eksperimen diberikan motivasi terlebih dahulu, sehingga siswa dapat semangat ketika belajar, sedangkan kelas kontrol tidak diberikan hal demikian, (2) Minat belajar siswa dalam kelas eksperimen tetap diperhatikan dalam pembelajaran, sedangkan dalam kelas kontrol minat belajar siswa kurang diperhatikan, (3) Kelas kontrol membutuhkan waktu yang cukup lama hingga proses pembelajaran selesai karena banyaknya tahapan yang harus dikerjakan, sedangan kelas eksperimen tidak memerlukan waktu seperti kelas kontrol. Hal ini jelas sudah berhasil membuktikan pemilihan strategi atau model atau metode belajar dalam rangkaian kegiatan 
pembelajaran sangatlah memberi dampak positif. Priatina (2018) menyatakan bahwa pemilihan dan penentuan metode belajar yang tepat sesuai dengan karakteristik materi atau bahan ajar yang diajarkan dapat memudahkan siswa untuk memahami konsep pelajaran dan pembelajaran menjadi lebih menyenangkan. Senada juga dengan pendapat Lestari, Andinny, dan Mailizar (2019), penerapan model pembelajaran yang tidak tepat dalam pembelajaran dapat menyebabkan matematika terkesan tidak menarik, karena itu guru harus mampu menggunakan berbagai macam model pembelajaran yang tepat dalam setiap materi pembelajaran yang disampaikan.

Penggunaan konteks etnomatematika dalam rangkaian kegiatan belajar yang dilakukan pada kelompok eksperimen dan kelompok kontrol merupakan bentuk pengaruh terhadap peningkatan kemampuan pemecahan masalah matematis siswa. Kegiatan belajar berbantuan konteks budaya akan lebih memiliki arti yang berkesan karena berkaitan dengan kehidupan sehari-hari siswa. Orey \& Rosa (2006) berpendapat bahwa program etnomatematika mempertimbangkan konsep matematika yang mencakup berpikir kritis, moral, holistik, dan budaya. Sementara itu, Utami, Nugroho, Dwijyanti, \& Sukarno (2018) menyebutkan bahwa budaya berdampak pada proses pemahaman materi oleh siswa, dimana pengetahuan yang dikenali dan dekat dengan siswa tentunya dapat lebih mudah dipahami dan bermakna. Penerapan konteks etnomatematika dalam kegiatan belajar dapat dikombinasikan dengan metode atau teknik tertentu yang ditetapkan. Hal ini menjadikan situasi rangkaian belajar matematika jauh lebih adaptif berupa penyelarasan antara materi pelajaran dengan unsur etnomatematika yang ada di daerah tersebut.

Sesuai dengan penelitian ini, konteks etnomatematika diterapkan dalam pembelajaran ARIAS dan STAD. Dalam proses pembelajaran, tingkat antusias siswa untuk belajar menjadi meningkat, pengetahuan mengenai budaya DKI Jakarta menjadi bertambah dan pembelajaran dengan berbantuan etnomatematika ternyata dapat mempertahankan kebudayaan yang sudah tidak dikenal lagi oleh siswa dan konteks etnomatematika merupakan alternatif cara yang dapat menjembatani antara matematika dengan budaya. Bentuk etnomatematika dalam pembelajaran ini diterapkan dalam soal aritmetika sosial dan didukung oleh gambar benda etnomatematika yang disebutkan dalam soal. Contoh soalnya adalah "Pak Rahmat adalah salah satu pedagang keliling kue semprong. Kue semprong adalah jajanan tradisional dari Betawi. Pak Rahmat menjual satu bungkus kue semprong dengan harga Rp15.000,00. Setiap harinya, ia membawa 25 bungkus untuk dijual. 
Pada saat hari hujan, 5 bungkus kue semprong basah dan tidak bisa dijual. Tentukan kerugian yang ditanggung Pak Rahmat dan hitunglah persentasenya!". Etnomatematika memberikan keuntungan dalam kegiatan belajar matematika, yaitu sebagai jembatan antara latar belakang pengetahuan siswa dengan pembelajaran matematika formal (Utami, Nugroho, Dwijyanti, \& Sukarno (2018); Dahlan \& Permatasari, 2017). Hartono \& Saputro (2018) juga berpendapat bahwa pembelajaran matematika sangat penting dipelajari siswa dan merupakan jembatan antara matematika kehidupan sehari-hari berdasarkan budaya lokal dengan matematika di sekolah, sehingga akan menjadi wadah untuk melestarikan budaya.

Sebelum dilakukan pengujian hipotesis, dilakukan uji pra syarat klasik analisis data yaitu uji normalitas dan homogenitas. Pengujian normalitas dilakukan untuk melihat distribusi dari data di kelompok sampel yang diteliti normal atau tidak.

Tabel 2. Uji Kenormalan Data Kemampuan Pemecahan Masalah Matematis

\begin{tabular}{ccccc}
\hline Kelas & $\mathrm{N}$ & $\chi_{\text {hitung }}^{2}$ & $\chi_{\text {tabel }}^{2}$ & Simpulan \\
\hline Eksperimen & 31 & 5,946 & 11,070 & Berdistribusi Normal \\
Kontrol & 31 & 6,735 & 11,070 & Berdistribusi Normal \\
\hline
\end{tabular}

Berdasarkan Tabel 2 terlihat bahwa setiap kelompok sampel penelitian berdistribusi normal. Pengujian homogenitas dimaksudkan untuk menunjukkan kesamaan varians data dari masing-masing kelompok sampel.

Tabel 3. Uji Homogenitas Data Kemampuan Pemecahan Masalah Matematis

\begin{tabular}{cccccc}
\hline Kelompok & $\mathrm{N}$ & Varians & $F_{\text {hitung }}$ & $F_{\text {tabel }}$ & Simpulan \\
\hline Eksperimen & 31 & 36,06 & 1,807 & 1,840 & Homogen \\
Kontrol & 31 & 19,96 & & & \\
\hline
\end{tabular}

Terlihat pada Tabel 3 yang ditampilkan bahwa kedua kelompok sampel mempunyai varians yang sama. Tabel 2 dan Tabel 3 menunjukan bahwa semua uji pra syarat klasik analisis data terpenuhi, selanjutnya dilakukan perhitungan pengujian hipotesis, yaitu dengan uji $t$ tidak berpasangan.

Tabel 4. Uji Perbedaan Kemampuan Pemecahan Masalah Matematis

\begin{tabular}{ccccc}
\hline Kelompok & $\mathrm{N}$ & $t_{\text {hitung }}$ & $t_{\text {tabel }}$ & Simpulan \\
\hline $\begin{array}{c}\text { Eksperimen } \\
\text { Kontrol }\end{array}$ & 31 & 3,179 & 2,003 & Ho ditolak \\
\hline
\end{tabular}


Merujuk pada hasil perhitungan pada Tabel 4, didapat hasil perhitungan berupa $t_{\text {hitung }}>t_{\text {tabel }}(3,179>2,003)$, sehingga $H_{0}$ ditolak. Artinya dapat disimpulkan untuk penerapan pembelajaran Assurance, Relevance, Interest, Assessment, Satisfaction berbantuan etnomatematika berpengaruh signifikan terhadap kemampuan pemecahan masalah matematis siswa.

Rata-rata kemampuan pemecahan masalah matematis siswa untuk kelompok eksperimen yang perlakuannya berupa penerapan pembelajaran ARIAS berbantuan etnomatematika lebih tinggi daripada rata-rata kemampuan pemecahan masalah matematis siswa untuk kelompok kontrol yang perlakuannya berupa pembelajaran kooperatif tipe STAD berbantuan etnomatematika. Hal ini tentunya menunjukkan bahwa terdeteksi dalam kegiatan pembelajaran di kelompok eksperimen terdapat tahap menumbuhkan rasa percaya diri siswa dengan membangun motivasi (assurance) dalam setiap pembelajaran, misalnya guru meningkatkan harapan siswa untuk belajar dengan menyusun materi pelajaran dari yang mudah ke yang sukar, tahap memadukan materi belajar ke dalam lingkungan pengalaman nyata dari siswa (relevance), misalnya mengkaitkan materi pelajaran dengan kehidupan sehari-hari siswa, tahap menumbuhkan minat atau perhatian belajar siswa (interest), misalnya guru menjelaskan materi pelajaran dengan strategi yang bervariasi, kemudian terdapat tahap evaluasi (assessment) yaitu dengan memberikan latihan mengenai pemecahan masalah, serta tahap memberikan penguatan dengan kaidah konsep penghargaan (satisfaction) yaitu dengan memberikan reward kepada siswa baik berupa verbal maupun non verbal. Sejalan dengan hasil penelitian dari Wulandari \& Supriyono (2014) bahwa proses pembelajaran memberikan stimulus yang positif kepada siswa karena sebelum kegiatan pembelajaran dimulai, siswa diberikan motivasi guna menumbuhkan kepercayaan diri dan mengaitkan materi dengan kehidupan sehari-hari sehingga siswa lebih berinisiatif dalam hal kegiatan pembelajaran sebaik-baiknya.

Hasil akhir dari rangkaian penelitian ini menunjukkan bahwa kelas eksperimen memiliki nilai rata-rata kemampuan pemecahan masalah matematis lebih tinggi dibandingkan dengan kelas kontrol. Namun, bukan berarti pembelajaran di kelas kontrol berupa penerapan STAD berbantuan etnomatematika tidak bagus. Perlakuan pembelajaran berupa kooperatif tipe $S T A D$ berbantuan etnomatematika sudah bagus untuk diterapkan karena dapat membangkitkan kinerja kelompok dan siswa cenderung jauh lebih aktif berinteraksi dengan temannya. Senada dengan hasil penelitian yang dilakukan oleh Priatina (2018) bahwa pembelajaran STAD mengajarkan 
siswa lebih aktif dalam proses pembelajaran dan berorganisasi serta bertukar ide untuk memecahkan masalah.

Berdasarkan temuan lapangan di saat proses penelitian dilaksanakan, pada saat penerapan pembelajaran kooperatif $S T A D$ berbantuan etnomatematika peneliti cenderung merasakan kekurangan yang signifikan dibandingkan dengan pembelajaran ARIAS. Kekurangan yang dirasakan oleh peneliti yaitu guru dan siswa harus membutuhkan waktu yang cukup panjang untuk menyesuaikan kegiatan pembelajaran sehingga target yang akan dicapai kurang maksimal. Sejalan dengan pendapat Rusman (2011) bahwa kegiatan pembelajaran STAD membutuhkan waktu yang lebih lama untuk siswa dan guru sehingga tidak mudah dalam hal mencapai target kurikulum.

Sedangkan pada saat peneliti menerapkan pembelajaran ARIAS berbantuan etnomatematika kekurangan pembelajaran ini tidak dirasakan. Terdapat beberapa pencapaian yang didapat oleh siswa, yaitu (1) siswa lebih bertanggung jawab terhadap tugas yang diberikan, (2) motivasi untuk belajar menjadi bertambah, (3) siswa dapat menunjukkan lebih disiplin, dan (4) kemampuan pemecahan masalah matematis siswa cenderung meningkat. Sehingga, pembelajaran ARIAS berbantuan etnomatematika lebih baik dibandingkan dengan pembelajaran STAD berbantuan etnomatematika. Hal ini sesuai dengan pendapat Ghasya \& Suryanti (2014) yang menyatakan bahwa dalam pembelajaran ARIAS terdapat tahap menumbuhkan rasa percaya diri siswa dengan diberikannya motivasi (assurance), tahap memadukan materi pembelajaran dengan kehidupan nyata siswa (relevance), tahap menumbuhkan minat atau perhatian belajar siswa (interest), kemudian terdapat tahap evaluasi (assessment), serta tahap menumbuhkan rasa bangga pada siswa dengan memberikan penguatan (satisfaction) sehingga tujuan pembelajaran dapat tercapai dan kemampuan pemecahan masalah matematis siswa meningkat.

Penelitian ini sejalan dengan hasil penelitian yang dilakukan oleh Ikhwarizmi \& Hartati (2015); Suryati, Masrukan \& Wardono (2013); serta Rahayu, Waluyo, Sugiman (2014), dimana pembelajaran ARIAS memberikan pengaruh terhadap pengaruh yang positif terhadap hasil belajar matematika, kemampuan pemecahan masalah siswa, serta meningkatkan kemampuan komunikasi matematis siswa.

Kemampuan pemecahan masalah matematis menjadi tolok ukur yang penting dalam proses pembelajaran matematika. Aisyah (2016) menyatakan bahwa kemampuan pemecahan masalah matematis sebagai salah satu 
bagian dari kurikulum matematika yang tentunya menjadi penting dalam proses pembelajaran. Dengan demikian, penerapan model atau metode untuk mendukung pembelajaran sangat penting. Hadirnya model pembelajaran memberikan dampak positif dalam meningkatkan kualitas dan mutu pembelajaran (Hakim, 2014). Secara keseluruhan dalam penelitian ini, pembelajaran ARIAS berbantuan etnomatematika dapat diterapkan untuk menjadikan kualitas hasil pembelajaran berupa kemampuan pemecahan masalah matematis siswa lebih baik.

\section{Simpulan}

Penelitian ini menyimpulkan bahwa penerapan pembelajaran ARIAS berbantuan etnomatematika berpengaruh secara signifikan terhadap kemampuan pemecahan masalah matematis siswa kelas VII di MTs AlWathoniyah 08 Jakarta. Berdasarkan hasil penelitian yang sudah selesai dilaksanakan, peneliti menyarankan bagi guru matematika diharapkan dapat lebih kreatif dan variatif dalam menggunakan model pembelajaran. Hal ini dikarenakan setiap model pembelajaran memiliki kekurangan dan kelebihan masing-masing, serta harus sesuai dengan kondisi kelas dan materi yang akan disampaikan kepada siswa.

\section{Daftar Pustaka}

Astriyani, A. (2016). Peningkatan Kemampuan Pemecahan Masalah Peserta Didik dengan Penerapan Model Pembelajaran Problem Possing. Jurnal Fibonacci, 2(1), 23-30.

Aisyah, N. (2016). Pengaruh Model Problem Based Learning Berbantuan Software Geogebra terhadap Kemampuan Pemecahan Masalah Matematika. JKPM (Jurnal Kajian Pendidikan Matematika), 1(2), 159-168.

Binangun, H. H., \& Hakim, A.R. (2016). Pengaruh Penggunaan Alat Peraga Jam Sudut terhadap Hasil Belajar Metematika. JKPM (Jurnal Kajian Pendidikan Matematika), 1(2), 204-214.

Dahlan, J.A. \& Pertamasari, R. (2018). Pengembangan Bahan Ajar Berbasis Etnomatematika dalam Pembelajaran Matematika Sekolah Menengah Pertama. JNPM (Jurnal Nasional Pendidikan Matematika), 2(1), 133-150.

Franklin, J. (2015). Aristotelian Realism in Philosophy of Mathematics. Elsevier.

Ghasya, D.A.V. \& Suryanti. (2014). Pengaruh Model Pembelajaran ARIAS (Assurance, Relevance, Interest, Assessment, Satisfaction) untuk Meningkatkan Kemampuan Berpikir Kreatif pada Mata Pelajaran IPA di Sekolah Dasar. JPGSD, 2(2), 1-16.

Hakim, A.R. (2014). Pengaruh Model Pembelajaran Generatif terhadap Kemampuan Pemecahan Masalah. Formatif: Jurnal Ilmiah Pendidikan MIPA, 4(20), 196-207.

Hartono \& Saputro, M. (2018). Ethnomatematics on Dayak Tabun Traditional Tools for School Mathematics Learning. International Journal of Trends in Mathematics Education Research, 1(3), 80-86.

Hayuningtyas, B. (2012). Diagnosis Kesulitan Belajar Aritmatika Sosial Ditinjau dari Aspek Kognitif Matematika (Pada Siswa Kelas VII MTs Muhammadiyah Blimbing, Polokarto, Sukoharjo). Disertasi. Fakultas Keguruan dan Ilmu Pendidikan. Surakarta: Universitas Muhammadiyah Surakarta. 
Hindayani, N. K. S., Sumantri, M., \& Parmiti, D. P. (2013). Pengaruh model pembelajaran Arias (Assurance, Relevance, Interst, Assessment dan Satisfaction) terhadap hasil belajar matematika di SD. MIMBAR PGSD Undiksha, 1(1), 1-11.

Ikhwarizmi \& Hartati, L. (2015). Penerapan Model Pembelajaran ARIAS terhadap Hasil Belajar Matematika Peserta Didik. Prosiding Seminar Nasional Pendidikan Matematika 2015. Jakarta: Universitas Indraprasta PGRI.

Kresma, E. N. (2014). Perbandingan Pembelajaran Konvensional dan Pembelajaran Berbasis Masalah terhadap Titik Jenuh Siswa maupun Hasil Belajar Siswa dalam Pembelajaran Matematika. Educatio Vitae, 1(1), 152-164.

Lestari, I., Andinny, Y., \& Mailizar, M. (2019). Pengaruh Model Pembelajaran Situation Based Learning dan Kemandirian Belajar terhadap Kemampuan Pemecahan Masalah Matematis. JNPM (Jurnal Nasional Pendidikan Matematika), 3(1), 95-108.

Liberna, H. (2012). Peningkatan Kemampuan Berpikir Kritis Matematis Siswa Melalui Penggunaan Metode Improve pada Materi Sistem Persamaan Linear Dua Variabel. Formatif: Jurnal Ilmiah Pendidikan MIPA, 2(3), 190-197.

Massarwe, K., Verner, I., \& Bshouty, D. (2012). Ethnomathematics and Multi-Cultural Education: Analysis and Construction of Geometric Ornaments. Journal of Mathematics and Culture, 6(1), 344-360.

Marliani, N. \& Hakim, A.R. (2015). Pengaruh Metode Belajar dan Kecemasan Diri terhadap Hasil Belajar Matematika Peserta Didik. JKPM (Jurnal Kajian Pendidikan Matematika) 1(1), 136-150.

NCTM. (2000). Principles and Standards for School Mathematics. Reston. Virginia: National Council of Teachers of Mathematics.

Orey, D.C. \& Rosa, M. (2006). Ethnomathematics: Cultural Assertions and Challenges Towards Pedagogical Action. The Journal of Mathematics and Culture, 4(1), 57-78.

Priatina, Y. (2018). Upaya Peningkatan Hasil Belajar Matematika Menggunakan Model Pembelajaran Kooperatif tipe STAD pada Materi Bangun Ruang Sisi Datar. JKPM (Jurnal Kajian Pendidikan Matematika), 4(1), 67-78.

Rachmawati, I. (2012). Eksplorasi Etnomatematika Masyarakat Sidoarjo. MATHEdenusa 1(1), $1-8$.

Rahayu, E.A., Waluyo, S.B., \& Sugiman. (2014). Keefektifan Model ARIAS Berbantuan Kartu Masalah untuk Meningkatkan Kemampuan Komunikasi Matematis Siswa. Jurnal Kreano, 5(1), 10-14.

Rahman, M. \& Amri, S. (2014). Model Pembelajaran ARIAS Terintegratif dalam Teori dan Praktek untuk Menunjang Penerapan Kurikulum 2013. Jakarta: Prestasi Pustaka.

Rusman. (2011). Model-model Pembelajaran. Jakarta: Rajawali Pers.

Siahaan, P., Setiawan, W., \& Sa'adah (2010). Penerapan Model ARIAS (Assurance, Relevance, Interest, Assessment, and Satisfaction) dalam Pembelajaran TIK (Teknologi Informasi dan Komunikasi). Jurnal Pendidikan Teknologi Informasi dan Komunikasi (PTK), 3(1), 2327.

Supriyanto, B. (2014). Penerapan Discovery Learning untuk Meningkatkan Hasil Belajar Siswa Kelas VI B Mata Pelajaran Matematika Pokok Bahasan Keliling dan Luas Lingkaran di SDN Tanggul Wetan 02 Kecamatan Tanggul Kabupaten Jember. Pancaran Pendidikan 3(2), 165-174.

Suryati, Masrukan, \& Wardono. (2013). Pengaruh Assesmen Kinerja dalam dalam Model Pembelajaran ARIAS terhadap Kemampuan Pemecahan Masalah. UJME (Unnes Journal of Mathematics Education), 2(3), 7-13. 
Utami, R., Nugroho, A., Dwijayanti, I., dan Sukarno, A. (2018). Pengembangan E-Modul Berbasis Etnomatematika untuk Meningkatkan Kemampuan Pemecahan Masalah. JNPM (Jurnal Nasional Pendidikan Matematika), 2(2), 268-283.

Wahyuni, A., Tias, A. A. W., \& Sani, B. (2013). Peran Etnomatematika dalam Membangun Karakter Bangsa. Prosiding Seminar Nasional Matematika dan Pendidikan Matematika. Yogyakarta: Universitas Negeri Yogyakarta.

Wulandari, K. \& Supriyono. (2015). Komparasi Kemampuan Pemecahan Masalah antara Pembelajaran ARIAS dan NHT pada Geometri SMP. UJME (Unnes Journal of Mathematics Education), 4(1), 41-49.

Yusuf, M.W., Saidu, I.I., \& Halliru. (2010). Etnomathematics (a Mathematical Game in Hausa Culture). International Journal of Mathematical Science Education, 3(1), 36-42. 